Supplement of Biogeosciences, 13, 4379-4388, 2016

http://www.biogeosciences.net/13/4379/2016/

doi:10.5194/bg-13-4379-2016-supplement

(C) Author(s) 2016. CC Attribution 3.0 License.

(c) (1)

Supplement of

\title{
Assessing approaches to determine the effect of ocean acidification on bacterial processes
}

Timothy J. Burrell et al.

Correspondence to: Timothy J. Burrell (timbo.burrell@gmail.com)

The copyright of individual parts of the supplement might differ from the CC-BY 3.0 licence. 


\section{Supplementary Material}

Supplementary figure legends

Supplementary figures S1-S6 


\section{Supplementary figure legends}

\section{Table S1}

Average LAP activity buffered in $0.1 \mathrm{M}$ Tris and MOPS at $\mathrm{pH} 8.1$ in coastal seawater $(\mathrm{n}=3 \pm$ SE).

\section{Figure S2}

Change in $\mathrm{pHt}$ in each treatment during trial $1(\mathrm{n}=3 \pm \mathrm{SD})$.

\section{Figure S3}

Change in $\mathrm{pHt}$ in each treatment during trial $2(\mathrm{n}=3 \pm \mathrm{SD})$.

\section{Figure S4}

Cell specific AG activity (mean $\pm \mathrm{SE}, \mathrm{n}=3$ ) in response to seawater acidified with $0.1 \mathrm{M} \mathrm{HCl}$ (A), bubbled with $\mathrm{CO}_{2}$-Air gas mixture (B) and $\mathrm{CO}_{2}$-Air gas mixture introduced through gas-permeable silicon tubing $(\mathrm{P})$ in trial 1.

\section{Figure S5}

Cell specific AAP activity (mean $\pm \mathrm{SE}, \mathrm{n}=3$ ) in response to seawater acidified with $0.1 \mathrm{M} \mathrm{HCl}(\mathrm{A})$, bubbled with $\mathrm{CO}_{2}$-Air gas mixture (B) and $\mathrm{CO}_{2}$-Air gas mixture introduced through gas-permeable silicon tubing $(\mathrm{P})$ in trial 1.

\section{Figure S6}

Cell specific AAP activity (mean $\pm \mathrm{SE}, \mathrm{n}=3$ ) in response to seawater acidified with $0.1 \mathrm{M} \mathrm{HCl}(\mathrm{A})$, bubbled with $\mathrm{CO}_{2}$-Air gas mixture (B) and $\mathrm{CO}_{2}$-Air gas mixture introduced through gas-permeable silicon tubing $(\mathrm{P})$ in trial 2. 


\section{Supplementary figures}

\section{Table S1}

\begin{tabular}{lll}
\hline Trial & Tris activity $\left(\mathrm{nmol} \mathrm{l}^{-1} \mathrm{~h}^{-1}\right)$ & MOPS activity $\left(\mathrm{nmol} \mathrm{l}^{-1} \mathrm{~h}^{-1}\right)$ \\
\hline 1 & $51.54( \pm 2.32)$ & $43.42( \pm 1.43)$ \\
2 & $35.92( \pm 0.81)$ & $29.34( \pm 1.08)$ \\
\hline
\end{tabular}


Figure S2

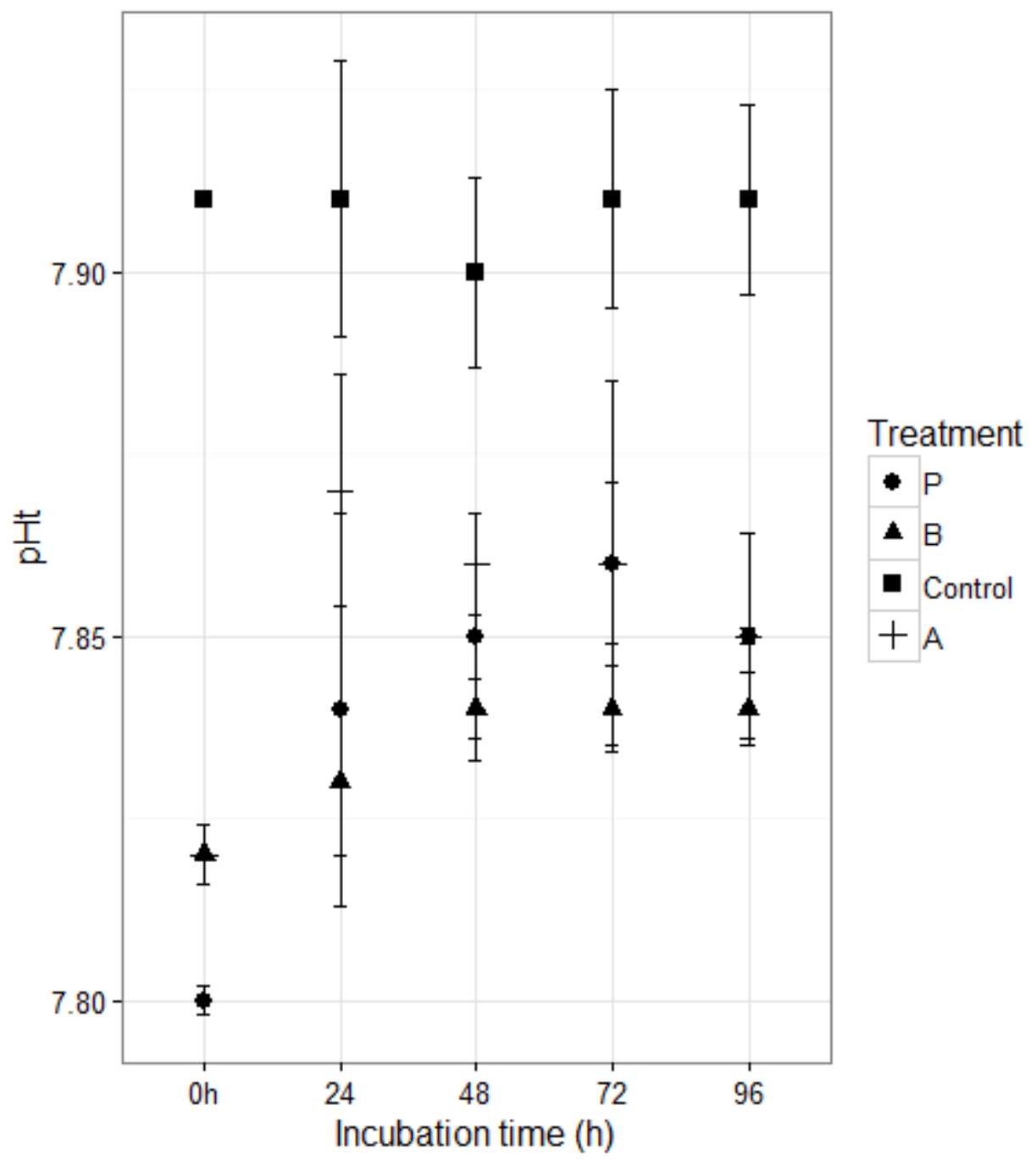


Figure S3

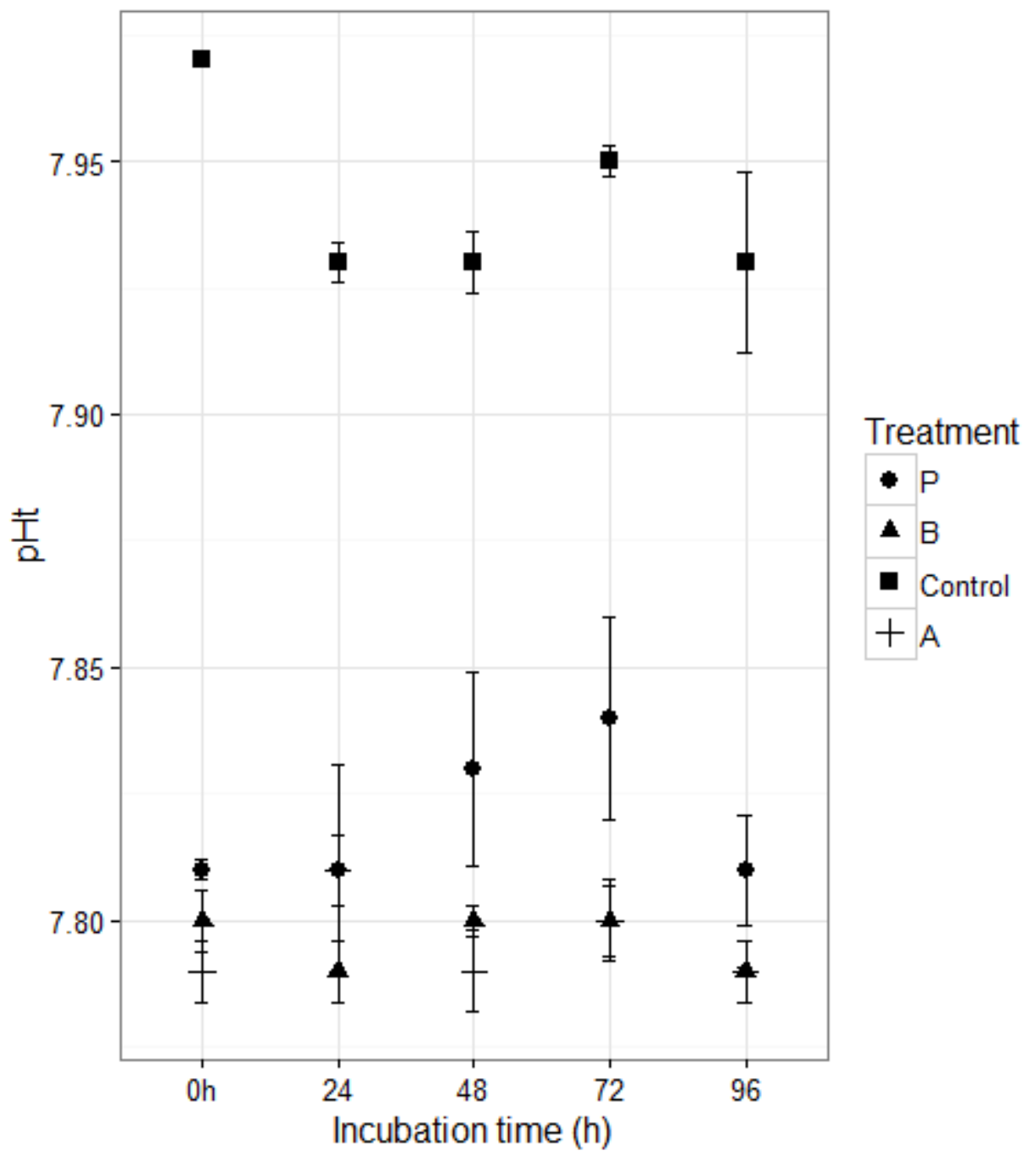


Figure S4

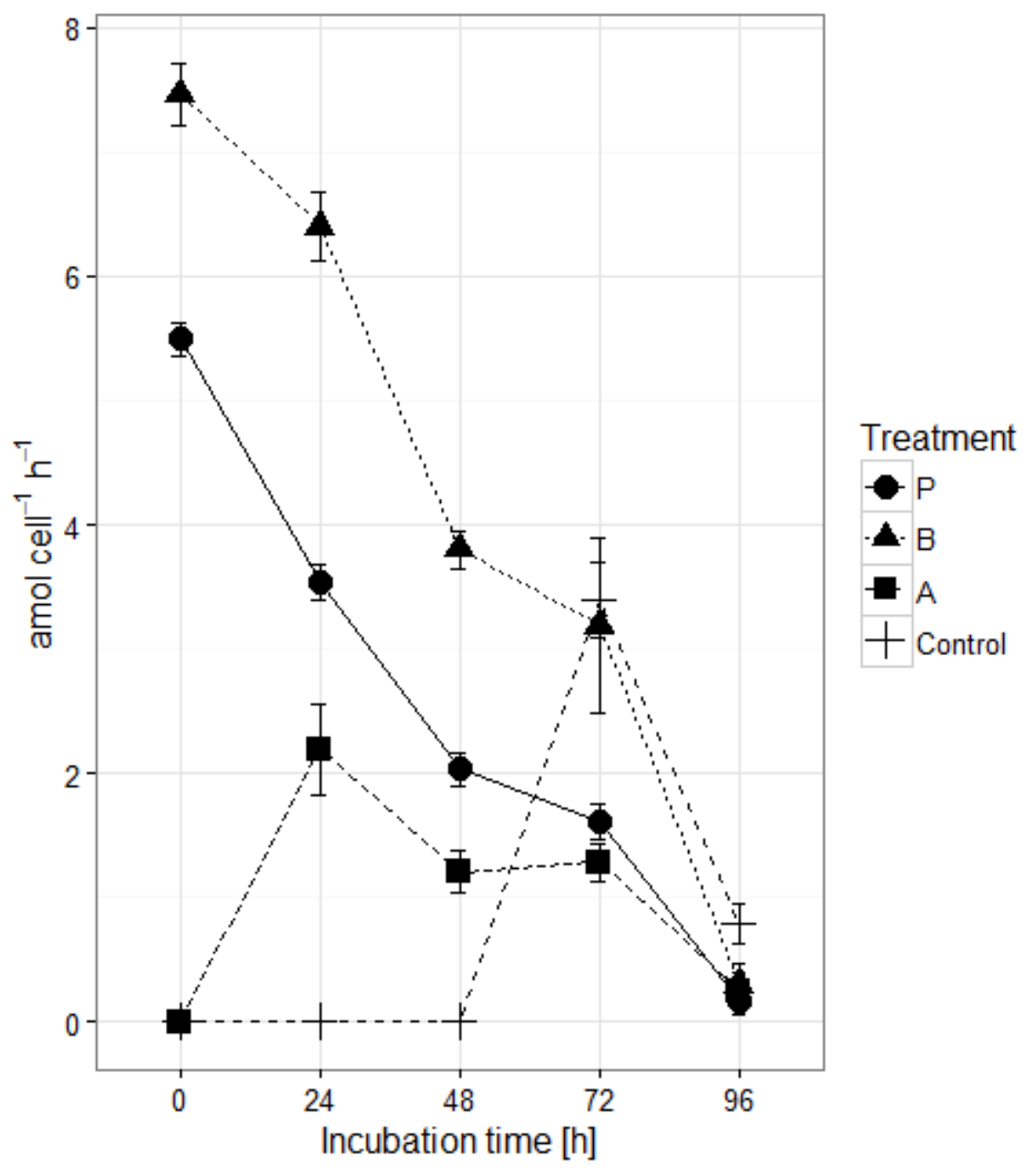


Figure S5

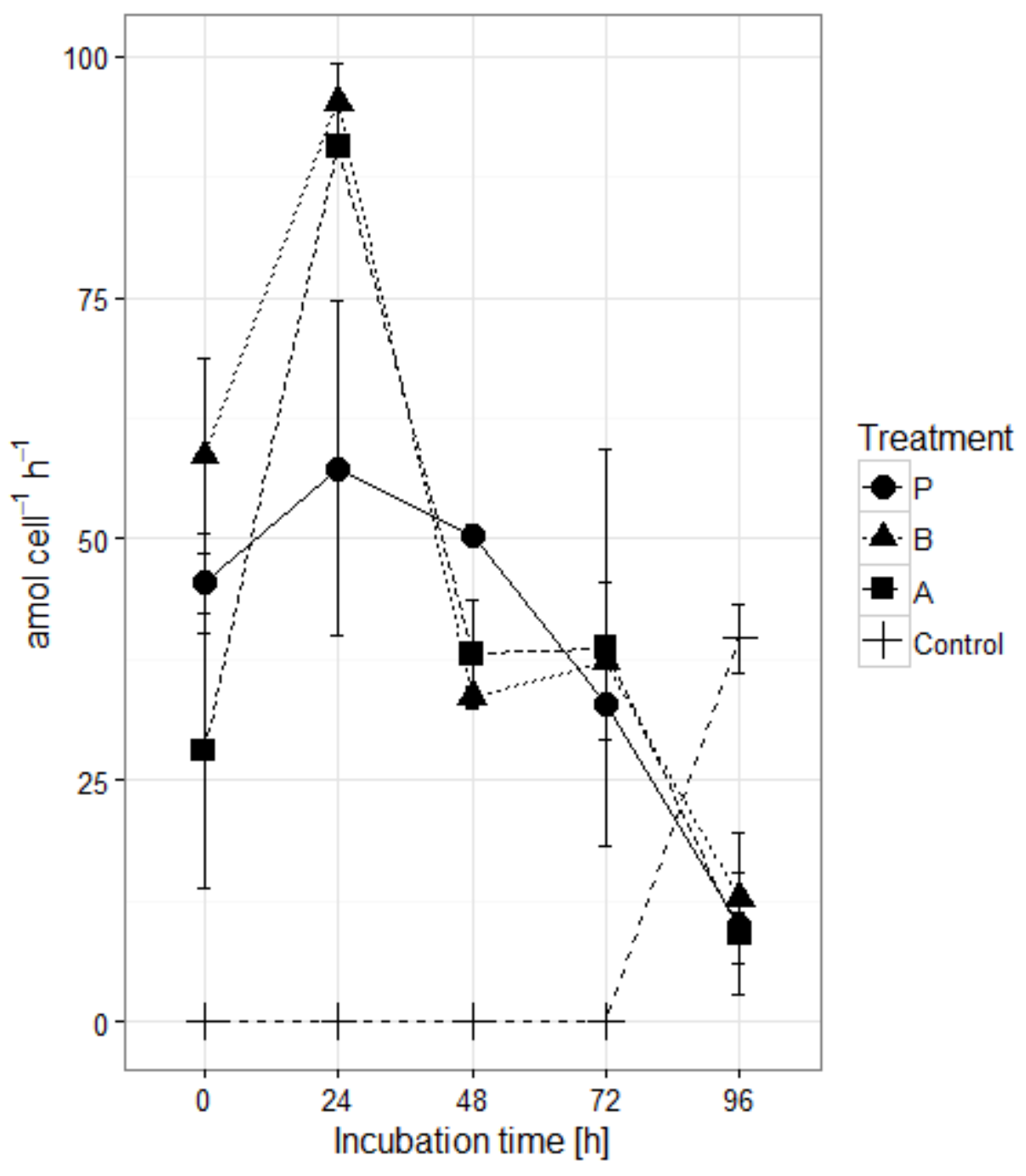


Figure S6

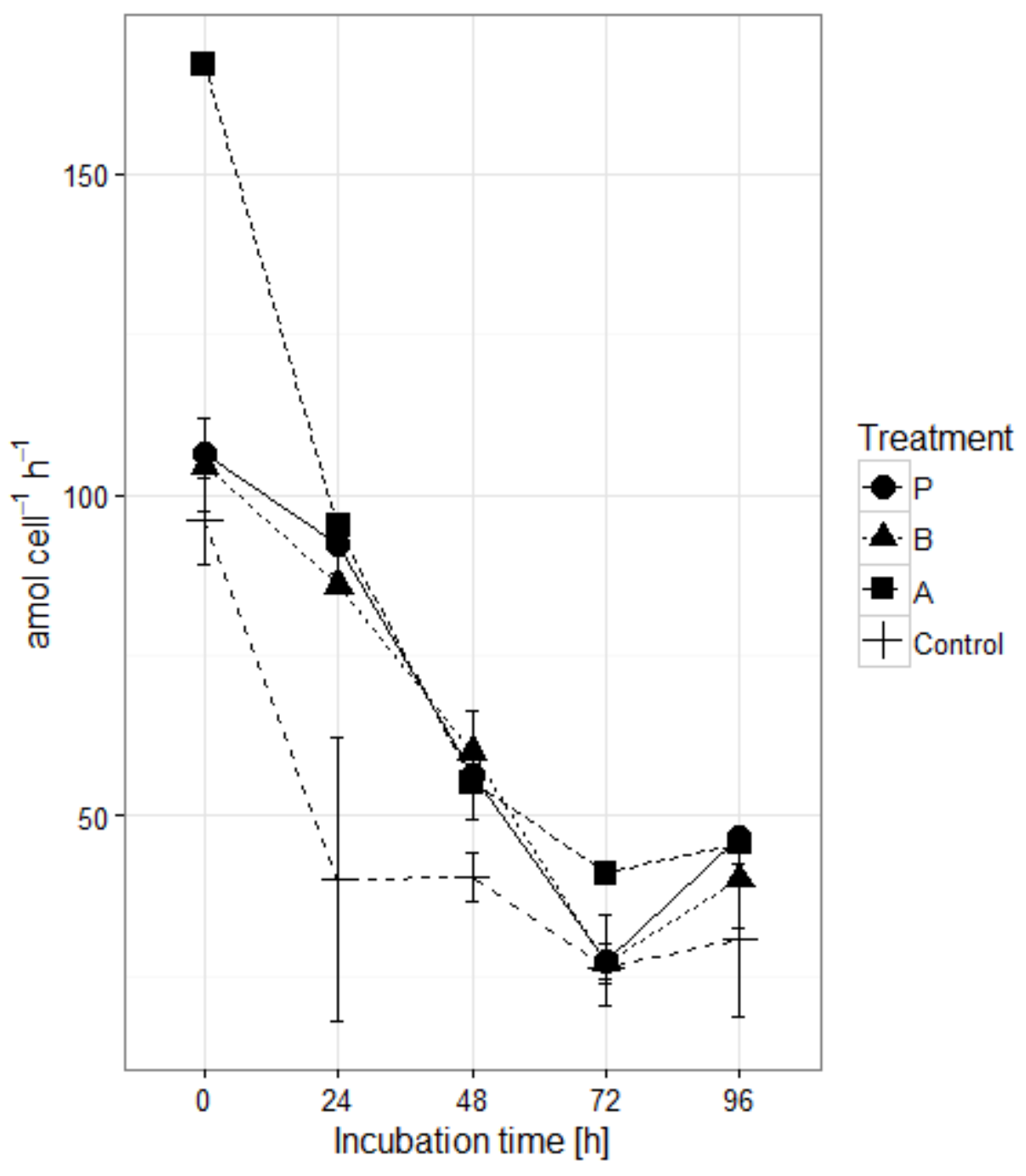

